\title{
THE OESTROUS CYCLE OF RATS AT HIGH ALTITUDE
}

\author{
JOSÉ DONAYRE \\ Departamento de Endocrinología, Instituto de Investigaciones de la Altura, \\ Universidad Peruana Cayetano Heredia, Lima, Peru
}

(Received 29th January 1968)

\begin{abstract}
Summary. Rats were exposed to an altitude of $14,000 \mathrm{ft}$ for up to 90 days, either in natural cold or at $23^{\circ} \mathrm{C}$. An initial tendency to anoestrus was probably due to the sudden change of environment. After about 30 days there was prolonged oestrus, probably as a result of low oxygen pressure. Oestrus was not as prolonged among the cold-exposed animals as among those at $23^{\circ} \mathrm{C}$, evidently owing to the anoestrous effect of cold. Recovery usually occurred on descent to sea level.
\end{abstract}

\section{INTRODUGTION}

Exposure to high altitudes leads to transient infertility in several species of mammals (Monge, San Martín, Atkins \& Castañón, 1945; San Martín, Atkins $\&$ Castañón, 1945). Both sexes are affected (Donayre, 1966). Probable causes include hypoxia and low environmental temperature. The oestrous cycle of rodents is extremely sensitive to environmental changes, of which temperature and light effects have been most studied. Extreme cold lowers the fertility of rats (Denison \& Zarrow, 1955), mice (Barnett, 1965) and golden hamsters (Grindeland \& Folk, 1962). In the present study an attempt has been made to clarify the effects of altitude on the oestrous cycle of the laboratory rat.

\section{MATERIAL AND METHODS}

One hundred and twenty female Holzman rats, with 4- to 5-day vaginal cycles during a 30-day period at sea level, were taken to our laboratories at $14,000 \mathrm{ft}$ and kept in wire-mesh cages holding six rats each. Bedding consisted of wood shavings. As at sea level, they were fed Purina Laboratory Chow and water freely. They were divided into three groups, exposed to the environment for 30 , 60 and 90 days respectively. Half the animals in each group were housed in a temperature-controlled area at $23 \pm 1^{\circ} \mathrm{C}$; the other half were put in quarters where the temperature ranged from 9 to $16^{\circ} \mathrm{C}$. Vaginal smears were taken every morning. At the end of the experimental period the rats were returned to sea level and examined daily for a further 30 days.

Percentage occurrence of oestrous days (pro-oestrous plus oestrous smears) was computed for each 10-day period and compared with the percentage of 
$35.4 \pm 1.63$ obtained for the first 30 -day period at sea level. This value resembles others for normal rats calculated from the literature (Carraro, Corbin, Fraschini \& Martini, 1965; Jarrett, 1965). In the account that follows, 'oestrus' refers to the detection of a vaginal smear of the oestrous type, not to behavioural oestrus.

\section{RESULTS}

The results of exposure at high altitude are summarized in Text-fig. 1.

The frequency of oestrus diminished during the early days of exposure. This was especially marked in the cold environment. During the 21- to 30-day period, values were not significantly different from controls. The rats in the warm room had a low value during the 1- to 10-day period, returned to normal during the 11- to 20-day period and turned to persistent oestrus during the 21to 30 -day period $(P<0.01)$.

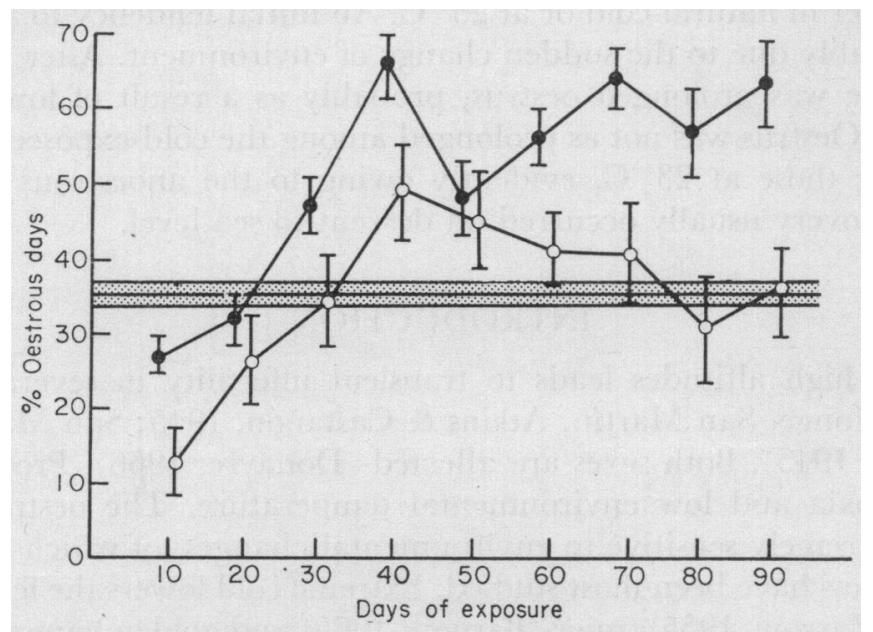

TEXT-FIG. 1. Incidence of oestrous smears on exposure to high altitude. 9 , Means for animals exposed in temperate quarters; $O$, means for animals exposed in natural cold. Vertical bars represent standard errors. The horizontal line represents the mean for control animals at sea level and the shaded area its standard error.

Both sub-groups of the rats exposed for 60 days displayed prolonged oestrus, but especially those in the warm environment. The figure for the 50- to 60day period for animals exposed to cold was not statistically different $(P>0 \cdot 10)$ from the control figure, and suggests a return to a normal cycle.

From 60 days of exposure there was a marked effect of temperature. The rats in the warm environment continued to display prolonged oestrus, but those in the cold had an incidence of oestrous days not significantly different from that of the controls.

The effects of return to sea level are summarized in Text-fig. 2. Rats which had been in a warm environment for 30 days at high altitude returned to a normal cycle after 10 days at sea level. Values for the 11- to 20-day and the 21to 30-day post-exposure periods were not statistically different from controls. Similar results were obtained from the animals exposed for 60 days. But those 
exposed for 90 days turned precipitously from persistent oestrus to anoestrus during the last 20 days of the post-exposure period.

Rats which had been exposed to cold responded in a rather erratic way on return to sea level. Those exposed for only 30 days to high altitude had 'normal' cycles for the first 10 days after exposure, but longer oestrus for the next 20 days $(P<0.02)$. After 60 days at high altitude there was a decrease in oestrous days for the first 10 days after exposure $(P<0.05)$, after which the cycles were evidently normal. Finally, animals exposed for 90 days maintained the normal cycle length already observed at high altitude.

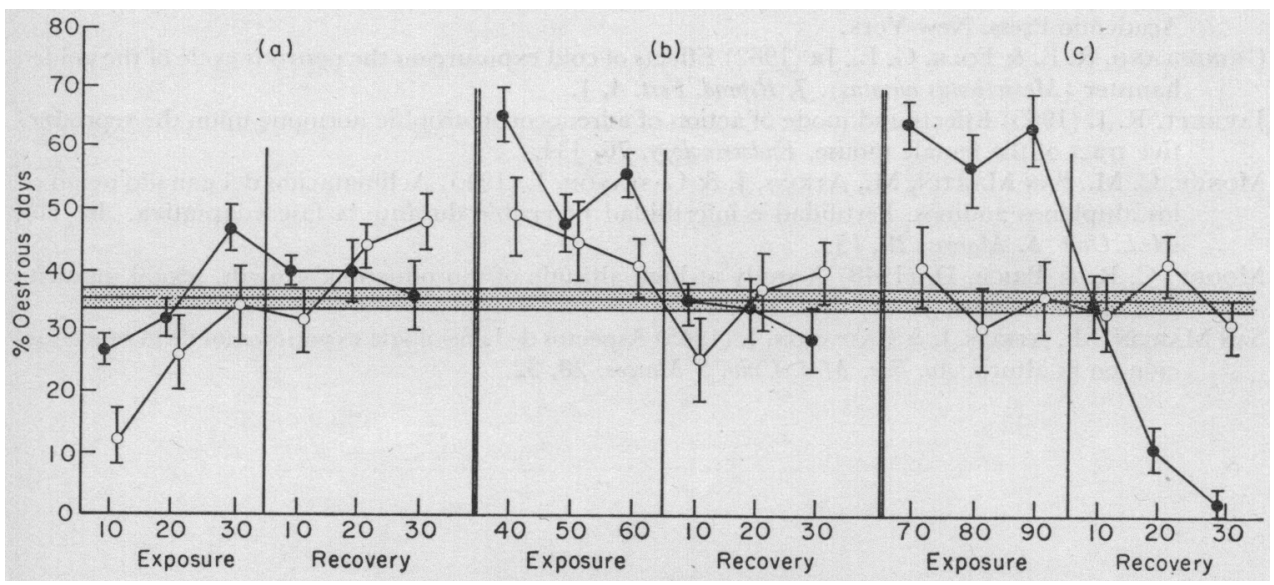

TEXT-FIG. 2. Recovery of oestrous cycle after exposure to high altitude. Symbols as in Text-fig. 1. (a) Recovery after 30-day exposure; (b) recovery after 60-day exposure; (c) recovery after 90 -day exposure.

\section{DISCUSSION}

The initial tendency to anoestrus at high altitude may have been due to the change of environment, or even to the effects of travel and the accompanying cold exposure. Animals exposed to cold had an even lower incidence of oestrous days than those kept in a warm environment. This suggests a summation of the effects of disturbance and cold, since cold itself tends to lengthen the oestrous cycle of mice (Barnett \& Coleman, 1959).

During the second phase, when there was prolonged oestrus, there was a corresponding difference between the two groups. Rats kept in the warm room continued to display prolonged oestrus, while those in the cold did not. Evidently the anoestrous effect of cold counteracted the persistent oestrus produced by hypoxia.

The changes in the oestrous cycle provoked by exposure to high altitude can account only in part for the decrease in fertility reported by other workers, since all animals alternated prolonged periods of oestrus with normal cycles. However, it could explain delayed pregnancy, such as that found by Moore \& Price (1948) at a similar altitude, and by Fernandez Cano (1959) under simulated conditions. 


\section{REFERENCES}

Barnett, S. A. (1965) Adaptation of mice to cold. Biol. Rev. 40, 5.

Barnett, S. A. \& Coleman, E. M. (1959) The effect of low environmental temperature on the reproductive cycle of female mice. . Endocr. 19, 232.

Carraro, A., Corbin, A., Fraschini, F. \& Martini, L. (1965) The effect of prepubertal treatment with reserpine on puberty, pituitary luteinizing hormone and the oestrous cycle of the rat. $\mathcal{F}$. Endocr. 32, 387.

Denison, M. E. \& Zarrow, M. X. (1955) Changes in oestrous cycle of rats during prolonged exposure to cold. Proc. Soc. exp. Biol. Med. 89, 632.

Donayre, J. (1966) Population growth and fertility at high altitude. In: Life at High Altitudes. PAHO Scientific Publications No. 140.

FERNANDEZ GANO, L. (1959) The effects of increase or decrease of body temperature or of hypoxia on ovulation and pregnancy in the rat. In: Recent Progress in the Endocrinology of Reproduction. Ed. C. W. Lloyd. Academic Press, New York.

Grindeland, R. E. \& Folk, G. E., JR (1962) Effects of cold exposure on the oestrous cycle of the golden hamster (Mesocricetus auratus). $\mathcal{F}$. Reprod. Fert. 4, 1.

JARRETT, R. J. (1965) Effects and mode of action of adrenocorticotrophic hormone upon the reproductive tract of the female mouse. Endocrinology, 76, 434.

Monge, G. M., San Martín, M., Atxins, J. \& Castañón, J. (1945) Aclimatación del ganado ovino en los altiplanos andinos. Fertilidad $\mathrm{e}$ infertilidad reversible durante la fase adaptativa. An. Fac. Med. Univ. S. Marcos, 28, 15.

Moore, G. R. \& Price, D. (1948) A study at high altitude of reproduction, growth, sexual maturity and organ weights. F. exp. Zool. 108, 171

San Martín, M., Atkins, J. \& Castañón, J. (1945) Aspectos de la fisiología experimental de la reproducción en la altura. An. Fac. Med. Univ. $S$ Marcos, 28, 32. 